\title{
Analisis Kesalahan Siswa Dalam Menyelesaikan Soal Matematika
}

\author{
Nur Fauziah Siregar* \\ Email: fauziah@iain-padangsidimpuan.ac.id \\ Fakultas Tarbiyah dan Ilmu Keguruan IAIN Padangsidimpuan
}

\begin{abstract}
This study aims to describe errors made by students in solving mathematical problems in the pythagorean theorem material. This research is a descriptive study with the object of research is class VIII-3 of Junior High School (Padangsidimpuan Middle School-7) T.A 2018/2019 which amounted to 21 students with heterogeneous levels of ability. The instrument collects data using essay tests. Data analysis is done by reducing data in the form of paragraphs and images, then drawing conclusions. The results of this study indicate that the common mistakes made by students in this study were more on type- 1 errors, namely understanding the concept of errors, followed by type- 3 errors, namely units of measurement of writing errors, then followed by type-2. error which is a calculation error, and type- 4 error is a mathematical procedure error.
\end{abstract}

Keywords: error analysis, mathematical problems, Pythagorean theorems, mathematics, understanding concepts

\begin{abstract}
Abstrak
Penelitian ini bertujuan untuk mendeskripsikan kesalahan yang dilakukan oleh siswa dalam pemecahan masalah matematika dalam materi teorema pythagoras. Penelitian ini merupakan penelitian deskriptif dengan objek penelitian adalah kelas VIII-3 Sekolah Menengah Pertama (SMPN-7 Padangsidimpuan) T.A 2018/2019 yang berjumlah 21 siswa dengan tingkat kemampuan yang heterogen. Instrumen mengumpulkan data menggunakan tes esai. Analisis data dilakukan dengan mereduksi data dalam bentuk paragraf dan gambar, kemudian menarik kesimpulan. Hasil penelitian ini menunjukkan bahwa kesalahan umum yang dilakukan oleh siswa dalam penelitian ini lebih pada kesalahan tipe-1, yaitu pemahaman konsep kesalahan, kemudian diikuti oleh kesalahan tipe-3, yaitu unit pengukuran kesalahan penulisan, kemudian diikuti oleh tipe-2. kesalahan yang merupakan kesalahan perhitungan, dan kesalahan tipe-4 yaitu kesalahan prosedur matematis.
\end{abstract}

Kata Kunci: analisis kesalahan, masalah matematika, teorema Phytagoras, matematika, pemahaman konsep

\footnotetext{
${ }^{*}$ Correspondence:

Email: fauziah@iain-padangsidimpuan.ac.id
} 


\section{A. PENDAHULUAN}

Kehidupan manusia tidak bisa lepas dari matematika karena manusia sering menjumpai masalah dalam kehidupan sehari-hari yang dalam pemecahan masalahnya tak jarang membutuhkan bantuan dari ilmu matematika, oleh sebab itu dalam sistem pendidikan Indonesia matematika merupakan salah satu mata pelajaran penting yang wajib dipelajari mulai dari tingkat sekolah dasar sampai perguruan tinggi. Walaupun matematika merupakan salah satu mata pelajaran penting, namun ada paradigma negatif yang mengiringi pelajaran matematika di benak para peserta didik.

Munculnya ketidaksukaan peserta didik terhadap matematika mungkin saja karena mereka menganggap matematika adalah mata pelajaran yang membosankan, membingungkan, sulit, dan bahkan menakutkan sehingga banyak peserta didik yang berusaha menghindari mata pelajaran matematika. Hal ini tentu sangat berakibat buruk dan menjadi fenomena yang memprihatinkan dalam dunia pendidikan terkhusus bagi perkembangan pendidikan matematika ke depan.

Pandangan negatif peserta didik terhadap matematika tentu mempengaruhi rendahnya motivasi peserta didik untuk mempelajari ilmu matematika dan mengakibatkan siswa sering kewalahan dalam menyelesaikan soal matematika yang pada akhirnya hasil belajar matematika siswa rendah. Hal tersebut sejalan dengan hasil studi pendahuluan di SMP Negeri 7 Padangsidimpuan, salah satu guru matematika kelas VIII-3 memberikan pernyataan bahwa masih banyak ditemukan siswa yang mengalami kesulitan dan melakukan kekeliruan dalam menyelesaikan soal matematika, dalam hal ini siswa tidak mengerti apa yang ditanyakan dalam soal, siswa salah dalam penggunaan rumus dan salah dalam perhitungan. Kesulitan-kesulitan siswa tersebut berdampak pada hasil belajar matematika siswa yang ternyata masih tergolong rendah karena banyak yang mendapat nilai dibawah KKM, walapun soal yang diberikan cukup mudah.

Masalah yang ditemui di SMP Negeri 7 Padangsidimpuan tersebut sama halnya dengan hasil penelitia yang dilakukan oleh Md. Aditya Dharma yang menemukan bahwa hasil wawancara dengan guru matematika di SD Negeri 1 Banjar Bali kecamatan buleleng tahun pelajaran 2015/2016, diketahui bahwa ternyata masih banyak terdapat siswa yang mengalami kesulitan dalam menyelesaikan soal matematika dalam bentuk cerita, memahami bahasa, apa yang ditanyakan dalam soal, dan dalam perhitungan. ${ }^{1}$

Solusi untuk memperbaiki hasil belajar siswa salah satunya adalah dengan mempelajari kelemahan-kelemahan apa saja yang dialami oleh siswa dengan cara menganalisis kesalahan atau kekeliruan siswa dalam menyelesaikan soal-soal matematika. Menurut Lerner dalam Mulyono ${ }^{2}$ mengemukakan bahwa ada beberapa sebab terjadinya berbagai kesalahan umum yang dilakukan oleh siswa dalam menyelesaikan soal-soal matematika yaitu: kurangnya pengetahuan tentang simbol, kurangnya pemahaman konsep dasar, lemahnya kemampuaan siswa dalam penggunaan proses jawaban yang benar, kesalahan perhitungan, dan tulisan

${ }^{1}$ Md. Aditya Dharma, dkk., Analisis Kemampuan Menyelesaikan Soal Cerita Pada Siswa Kelas IV Tahun Pelajaran 2015/2016 di SD Negeri 1 Banjar Bali (Bali: Universitas Pendidikan Ganesha, 2016), hlm. 3.

${ }^{2}$ Mulyono Abdurrahman, Pendidikan Bagi Anak Berkesulitan Belajar (Jakarta: PT. Rineka Cipta, 1999), hlm. 262. 
yang tidak rapi sehingga siswa melakukan kekeliruan karena tidak mampu lagi membaca tulisannya sendiri.

Dengan adanya permasalahan dalam studi pendahuluan yang telah dilaksanakan di SMP Negeri 7 Padangsidimpuan tersebut, maka perlu dilakukan suatu penelitian untuk menganalisis kesalahan siswa menyelesaikan soal matematika dalam bentuk soal cerita. Penelitian ini penting dilakukan agar dapat mengetahui kemampuan siswa dan kesalahan-kesalahan apa saja yang dilakukan siswa dalam menyelesaikan soal. Sehingga dengan demikian, untuk kedepan diharapkan kesalahan yang dilakukan siswa dalam menyelesaikan soal matematika dapat diminimalisir dan ditemukan solusi atas kelemahan-kelemahan siswa dalam meyelesaikan soal-soal matematika di kemudian hari.

\section{Jenis-Jenis Kesalahan Siswa}

Terkadang ada kalanya seorang siswa mengalami kesulitan untuk memecahkan sebuah persoalan dalam suatu pembelajaran baik itu dalam ujian ataupun latihan soal-soal matematika. Padahal mereka telah berusaha semaksimal mungkin namun belum juga berhasil. Sebagai seorang pendidik kita harus mengetahui sebagian besar kelemahan-kelemahan dari siswa yang kita didik, dan kita harus tahu kesalahan-kesalahan yang sering dilakukan siswa dalam menyelesaikan soal matematika. Menurut Yunia Mulyani Azia dalam penelitiannya menemukan bahwa ada beberapa jenis kesalahan-kesalahan yang dilakukan siswa dalam mengerjakan soal antara lain: ${ }^{3}$

1. Kesalahan konsep, yaitu kesalahan yang dilakukan siswa pada waktu mengerjakan soal matematika yang disebabkan karena siswa belum faham konsep matematika yang diperlukan.

2. Kesalahan perhitungan, yaitu kesalahan yang disebabkan karena siswa salah menghitung, akan tetapi konsep matematika yang digunakan sudah benar.

3. Kesalahan informasi, yaitu kesalahan siswa dalam memahami maksud soal, hal ini yang sering terjadi untuk soal-soal yang berbentuk soal cerita.

Jenis-jenis kesalahan siswa yang diutarakan Yunia Mulyani Azia sama halnya dengan pendapat Arti Sriati yang menyatakan bahwa pada dasarnya kesalahan pokok siswa dalam menyelesaikan soal matematika adalah: ${ }^{4}$

1. Kesalahan dalam membuat pemodelan matematika.

2. Kesalahan konsep, yaitu kesalahan dalam memahami konsep matematika.

3. Kesalahan strategi, yaitu kesalahan yang terjadi karena siswa memilih cara mengerjakan yang tidak tepat.

3 Yunia Mulyani Azia, Upaya Mengatasi Kesulitan Siswa Belajar Geometri dengan Pengajaran Remidial Kelompok dan Remedial Bersama di Sekolah Lanjutan Tingkat Pertama, (2013, Diakses dari http://digilib.upi.edu/pasca/available/etd-1011106-131035/), hlm. 12.

${ }^{4}$ Arti Sriati, Kesulitan Belajar Matematika pada Siswa SMA (Pengkajian Diagnosa) (Yogyakarta: Jurnal Kependidikan, 1994), hlm. 4. 
4. Kesalahan sistematik, yaitu kesalahan yang berkenaan dengan pemilihan yang salah atas teknik ekstrapolasi.

5. Kesalahan tanda, yaitu kesalahan dalam memberikan atau menulis tanda atau notasi matematika.

6. Kesalahan hitung, yaitu kesalahan dalam melakukan operasi matematika.

Namun dalam penelitian ini, jenis-jenis kesalahan yang dilakukan siswa dalam menyelesaikan soal matematika dibagi ke dalam beberapa tipe kesalahan. Adapun tipe kesalahan disini dikelompokkan ke dalam 4 jenis/tipe, yaitu:

1. Kesalahan tipe-1: yaitu kesalahan konsep.

2. Kesalahan tipe-2: yaitu kesalahan perhitungan.

3. Kesalahan tipe-3: yaitu kesalahan penulisan satuan ukur.

4. Kesalahan tipe-4: yaitu kesalahan prosedur.

\section{Penyelesaian Soal Matematika}

Soal matematika yaang dibahas pada penelitian ini adalah soal yang disajikan dalam bentuk cerita. Soal cerita adalah rangkaian kalimat yang berkaitan dengan keadaan siswa dalam kehidupan sehari-hari yang mengandung masalah dan menuntut siswa untuk menyelesaikan masalah tersebut. ${ }^{5}$ Menurut Rahardjo soal cerita matematika adalah soal matematika yang terkait dengan kehidupan sehari-hari untuk dicari penyelesaiannya menggunakan kalimat matematika yang memuat bilangan, operasi hitung, dan relasi. ${ }^{6}$ Menurut Asih dalam menyelesaikan soal cerita harus melalui langkah berikut: memahami soal dengan menuliskan apa yang diketahui dan ditanyakan, dilanjutkan dengan membuat model matematika dan pertidaksamaannya, kemudian menyelesaikan komputasi dan aljabarnya dengan benar. ${ }^{7}$

Sedangkan menurut Soedjadi untuk menyelesaikan soal cerita matematika dapat ditempuh dengan langkah-langkah sebagai berikut: ${ }^{8}$ a) Membaca soal dengan cermat untuk menangkap makna pada tiap kalimat, b) Memisahkan dan mengungkapkan apa yang diketahui dalam soal dan apa yang ditanyakan oleh soal, c) Membuat model matematika dari soal, d) Menyelesaikan model matematika menurut aturan matematika sehingga mendapat jawaban dari soal, e) Mengembalikan jawaban ke dalam konteks soal yang ditanyakan.

Berdasarkan pendapat para ahli diatas, dapat disimpulkan bahwa soal cerita adalah merupakan soal-soal hitungan matematika yang dimodifikasi ke dalam sebuah cerita yang berkaitan dengan permasalahan kehidupan sehari-hari. Pada dasarnya soal cerita dalam matematika dapat dipecahkan dengan memahami maksud soal tersebut yaitu memahami apa yang diketahui dan apa yang ditanya,

\footnotetext{
${ }^{5}$ Syamsuddin, H., Kesulitan Siswa Kelas V SD Menggunakan Langkah-langkah Pemecahan Masalah dalam Menyelesaikan Soal Cerita (Surabaya: UNESA, 2001), hlm. 127.

${ }^{6}$ Rahardjo, M. A., Pembelajaran Soal Cerita Operasi Hitung Campuran di Sekolah Dasar, (Online: Modul Matematika SD dan SMP Program Bermutu, 2011).

${ }^{7}$ Asih, I M., Peningkatan Kemampuan Siswa SMAN 8 Denpasar dalam Menyelesaikan Soal Cerita Pokok Bahsan Program Linear Mata Pelajaran Matematika (Denpasar: Universitas Udayana, 2011), hlm. 68.

8 Muncarno, Penerapan Model Penyelesaian Soal Cerita dengan Langkah-langkah Pemecahan Masalah untuk Meningkatkan Prestasi Belajar Matematika Siswa Kelas 1 SMP (Jurnal NUANSA Pendidikan, Vol. VI, No. 1), hlm. 19.
} 
kemudian menggunakan kalimat matematika untuk menerapkan konsep dan prinsip matematika, selanjutnya siswa dapat menyelesaikan soal dengan melakukan perhitungan dengan benar.

\section{B. METODE PENELITIAN}

Metode yang digunakan dalam penelitian ini adalah penelitian deskriptif dengan pendekatan kualitatif, yaitu penelitian yang berusaha untuk mendeskripsikan, menggambarkan atau melukiskan suatu gejala peristiwa dan kejadian secara sistematis sesuai dengan keadaan yang ada di dalam suatu populasi. Dengan demikian, penelitian ini mendeskripsikan kesalahan-kesalahan yang dilakukan siswa dalam menyelesaikan soal pada bidang studi matematika materi teorema Pythagoras di SMP Negeri 7 Padagsidimpuan.

Agung menyatakan bahwa penelitian deskriptif bisa mendeskripsikan suatu keadaan saja, tetapi bisa juga mendeskripsikan keadaan dalam tehapantahapan perkembangan. ${ }^{9}$ Penelitian ini dilakukan untuk mendeskripsikan suatu fenomena yang ada secara sistematis dengan objek yang diteliti adalah peserta didik di kelas VIII-3 SMP Negeri 7 Padangsidimpuan T.A 2018/2019 yang berjumlah 21 orang yang terdiri dari 8 orang siswa perempuan dan 13 orang siswa laki-laki dengan tingkat kemampuan heterogen.

Adapun instrumen pengumpulan data yang digunakan dalam penelitian ini adalah tes essay (uraian) yang bertujuan untuk mengetahui kemampuan siswa dan kesalaha-kesalahan yang dilakukan siswa dalam menyelesaikan soal matematika dalam bentuk soal cerita sebanyak 5 soal dengan materi teorema Pythagoras. Dalam penyusunan tes, terlebih dahulu disusun kisi-kisi soal, yang dilanjutkan dengan menyusun soal beserta kunci jawaban.

Selanjutnya teknik analisis data yang digunakan dalam penelitian ini adalah terdiri dari mereduksi data, menyajikan data, dan menarik kesimpulan. Data yang diperoleh pada penelitian ini berupa lembar jawaban siswa, data tersebut akan direduksi. Hal ini diartikan sebagai kegiatan yang terkait dengan menyeleksi, menyederhanakan, mengelompokkan, memfokuskan, semua data yang telah diperoleh dari hasil tes jawaban siswa. Tahap selanjutnya adalah peneliti menyajikan data yang merupakan hasil reduksi yaitu data berupa deskripsi hasil pekerjaan siswa pada soal tes tertulis. Kemudian kegiatan yang terkhir dalam tahap ini adalah penarikan kesimpulan dari data yang telah diperoleh berdasarkan hasil dari tes jawaban siswa terhadap soal yang telah diberikan.

\section{HASIL DAN PEMBAHASAN}

Seperti yang telah diutarakan pada bagian sebelumnya, untuk mengatahui kesalahan-kesalahana yang dilakukan oleh siswa kelas VIII-3 SMP Negeri 7 Padangsidimpuan dalam menyelesaikan soal, maka disusunlah tes yang akan diberikan kepada siswa dengan menggunakan soal cerita sebanyak 5 soal

${ }^{9}$ Agung, A. A. Gede, Metode Penelitian Pendidikan, (Malang: Aditya Media Publishing, 2014), hlm. 26. 
tentang materi teorema Pythagoras. Berikut ini akan disajikan dalam bentuk tabel hasil dari pekerjaan siswa menyelesaikan soal cerita matematika materi teorema Pythagoras yang diklasifikasikan dalam benar, salah, dan tidak dijawab. Jumlah siswa seluruhnya adalah 21 orang.

Tabel 1. Hasil Persentase Jawaban Siswa Secara Klasikal

\begin{tabular}{|c|c|c|c|c|c|c|}
\hline \multirow[b]{2}{*}{ Jawaban } & \multicolumn{5}{|c|}{ SOAL } & \multirow{2}{*}{$\begin{array}{c}\text { Jumlah } \\
\text { Rata- } \\
\text { rata }\end{array}$} \\
\hline & No. 1 & No. 2 & No. 3 & No. 4 & No. 5 & \\
\hline Benar & $\begin{array}{ll}19 & \text { siswa } \\
= & 90,47 \\
\% & \end{array}$ & $\begin{array}{ll}13 & \text { siswa } \\
= & 61,90 \\
\% & \end{array}$ & $\begin{array}{l}15 \text { siswa } \\
= \\
71,42 \%\end{array}$ & $\begin{array}{l}5 \text { siswa } \\
=23,80 \\
\%\end{array}$ & $\begin{array}{l}0 \text { siswa }= \\
0 \%\end{array}$ & $49,518 \%$ \\
\hline Salah & $\begin{array}{l}2 \text { siswa }= \\
9,52 \%\end{array}$ & $\begin{array}{l}8 \text { siswa }= \\
38,09 \%\end{array}$ & $\begin{array}{l}6 \text { siswa }= \\
28,57 \%\end{array}$ & $\begin{array}{l}16 \\
\text { siswa = } \\
76,19 \%\end{array}$ & $\begin{array}{l}21 \text { siswa } \\
=100 \%\end{array}$ & $50,47 \%$ \\
\hline $\begin{array}{l}\text { Tidak } \\
\text { dijawab }\end{array}$ & $0 \%$ & $0 \%$ & $0 \%$ & $0 \%$ & $0 \%$ & $0 \%$ \\
\hline
\end{tabular}

Keterangan:

Soal No.1 sampai No.5 = Berupa Pertanyaan yang berkaitan dengan materi teorema Pythagoras.

Analisis hasil jawaban siswa terhadap soal yang diberikan mengenai materi teorema pythagoras mulai soal nomor 1 sampai soal nomor 5 secara deskriptif dapat disjikan pada paparan berikut ini:

\section{Nomor 1}

Soal nomor 1 adalah soal yang bertujuan untuk mengetahui apakah peserta didik dapat memahami pengertian dari teorema pythgoras dan menjelaskan contohnya jika diterapkan dalam kehidupan sehari-hari. Berdasarkan Tabel.1 ditemukan bahwa siswa yang menjawab dengan benar pada soal nomor 1 sebanyak 19 orang siswa dengan persentase sebesar $90,47 \%$, dan menjawab salah sebanyak 2 orang siswa dengan persentase sebesar $9,52 \%$, serta yang tidak menjawab sebesar $0 \%$. Sehingga dapat disimpulkan bahwa 2 siswa dikategorikan mengalami kesalahan tipe-1, yaitu salah ataupun keliru dalam memahami konsep teorema pythagoras karena diasumsikan siswa tidak mengerti kegunaan ataupun pengaplikasian teorema pythagoras dalam kehidupan sehari-hari sehingga siswa tidak bisa menyebutkan contohnya. 


\section{Ragam Jawaban Siswa:}
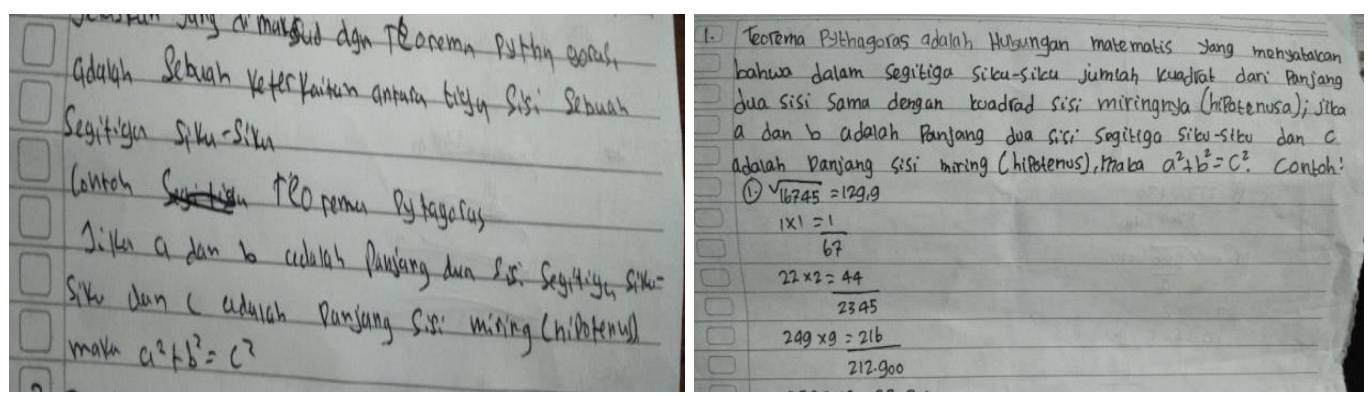

Gambar 1: Ragam Jawaban Siswa Pada Soal Nomor Satu

\section{Nomor 2}

Soal nomor 2 adalah soal yang bertujuan untuk mengetahui apakah peserta didik mampu menerapkan konsep teorema pythagoras secara algoritma. Berdasarkan Tabel.1 ditemukan bahwa siswa yang bisa memberikan jawaban dengan benar pada soal nomor 2 sebanyak 13 orang dengan persentase sebesar $61,90 \%$, dan yang menjawab salah sebanyak 8 orang siswa dengan persentase sebesar $38,09 \%$, serta yang tidak menjawab sebesar 0\%. Sehingga dapat disimpulkan bahwa sebanyak 8 orang siswa melakukan 4 tipe kesalahan, yaitu: siswa dikategorikan mengalami kesalahan tipe- 1 dimana siswa keliru dalam memahami konsep dasar teorema pythagoras secara benar karena siswa masih bingung mengaplikasikan rumus ke dalam masalah yang ada pada soal. Selain itu, siswa tidak paham pada saat bagaimana suatu rumus tersebut digunakan karena ditemukan banyak jawaban siswa menjawab soal hanya menjumlahkan, atau mengurangkan serta mengalikan bilangan yang diketahui pada soal. Selanjutnya, siswa melakukan kesalahan pada tipe-2, yaitu perhitungan yang dilakukan siswa masih salah. Kemudian, siswa melakukan kekeliruan tipe-3, yaitu siswa keliru dalam memakai satuan ukur $(\mathrm{cm})$, dan tidak menuliskan jawaban dengan menggunakan notasi matematika yang benar. Selanjutnya, siswa melakukan kesalahan pada tipe-4 yaitu, kesalahan prosedur dimana kurangnya kemampuan siswa dalam bidang aljabarnya (menurunkan rumus/ memutar rumus). Selain itu, diasumsikan bahwa siswa kurang teliti dalam membaca soal, sehingga pernyataan dan informasi yang tersirat dalam soal tidak dipahami dengan baik, serta jika ditanya para siswa mengatakan sudah lupa pada penggunaan rumus teorema pythagoras secara algoritma.

Ragam Jawaban Siswa:
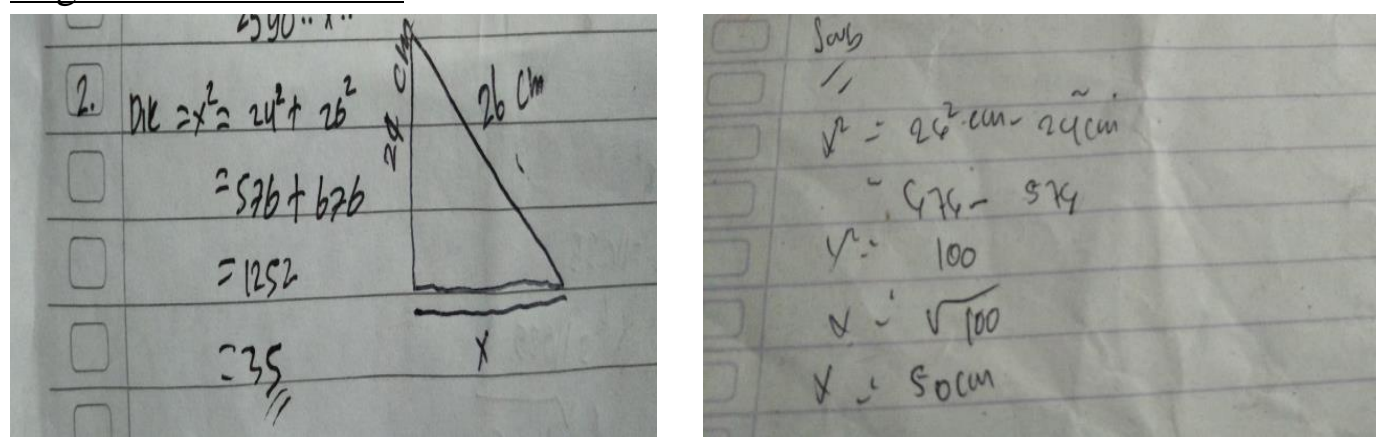

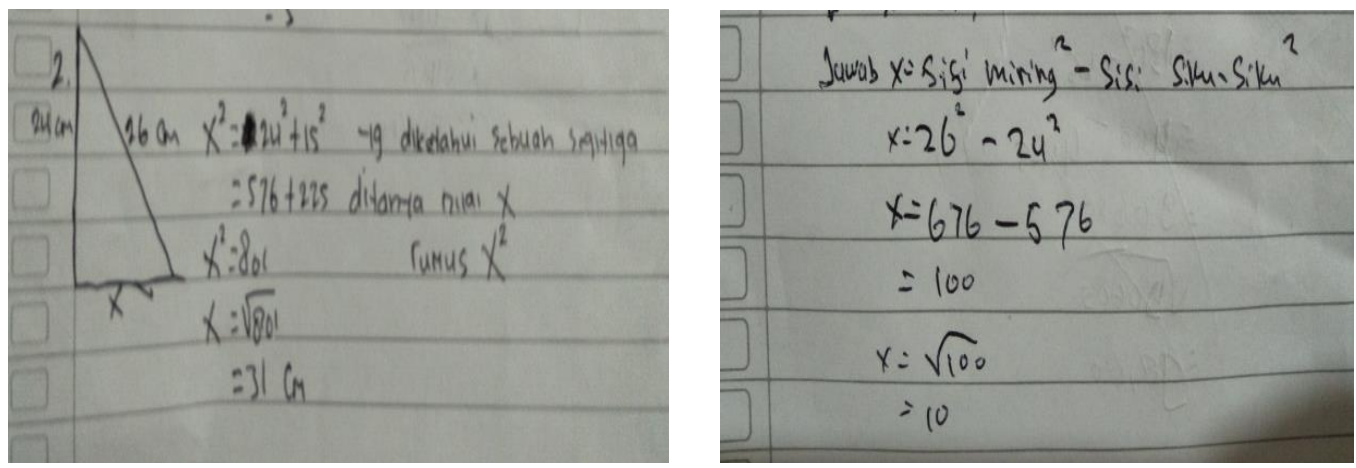

Gambar: Ragam Jawaban Siswa pada Soal Nomor Dua

\section{Nomor 3}

Soal nomor 3 adalah soal yang bertujuan untuk mengetahui apakah peserta didik mampu mengembangkan konsep teorema pythagoras yang telah dipelajari. Berdasarkan Tabel.1 ditemukan bahwa sebanyak 15 orang siswa yang menyelesaikan jawaban dengan benar pada persentase sebesar $71,42 \%$, dan yang menjawab salah sebanyak 6 orang siswa dengan persentase sebesar $28,57 \%$, serta yang tidak menjawab sebesar 0\%. Sehingga dapat disimpulkan bahwa sebanyak 16 siswa melakukan 4 tipe kesalahan, yaitu: siswa dikategorikan mengalami kesalahan tipe-1 dimana siswa keliru dalam pemahaman konsep dasar teorema pythagoras secara benar karena karena ditemukan banyak jawaban siswa menjawab soal hanya menjumlahkan, atau mengurangkan serta mengalikan bilangan yang diketahui pada soal tanpa memaknai penggunaan rumus teorema pythagoras. Selanjutnya, siswa melakukan kesalahan pada tipe-2, yaitu perhitungan yang dilakukan siswa masih salah. Kemudian, siswa melakukan kesalahan tipe-3 dimana siswa tidak menuliskan satuan ukur (m) pada jawabannya. Terakhir ditemukan juga siswa melakukan kesalahan tipe-4 yaitu kesalahan prosedur matematis dimana kurangnya kemampuan siswa dalam bidang aljabarnya, karena yang ditanya pada soal adalah sisi miring $\left(\mathrm{c}^{2}\right)$ tapi yang ditulis siswa $a^{2}$ dan rumus $a^{2}$ itu salah, yang seharusnya rumusnya $a^{2}=c^{2}-b^{2}$ tapi ditulis siswa menjadi $a^{2}=b^{2}+c^{2}$. Selain itu, diasumsikan siswa masih rendah dalam memahami maksud soal dan kurang teliti membaca soal, sehingga informasi yang terdapat pada soal kurang dipahami maknanya, kemudian mereka hanya menyelesaikan pada tahap persamaan bentuk gambar dengan yang ada pada pikiran mereka saja dan jika ditanya para siswa mengatakan sudah lupa rumus teorema pythagoras.

\section{Ragam Jawaban Siswa:}
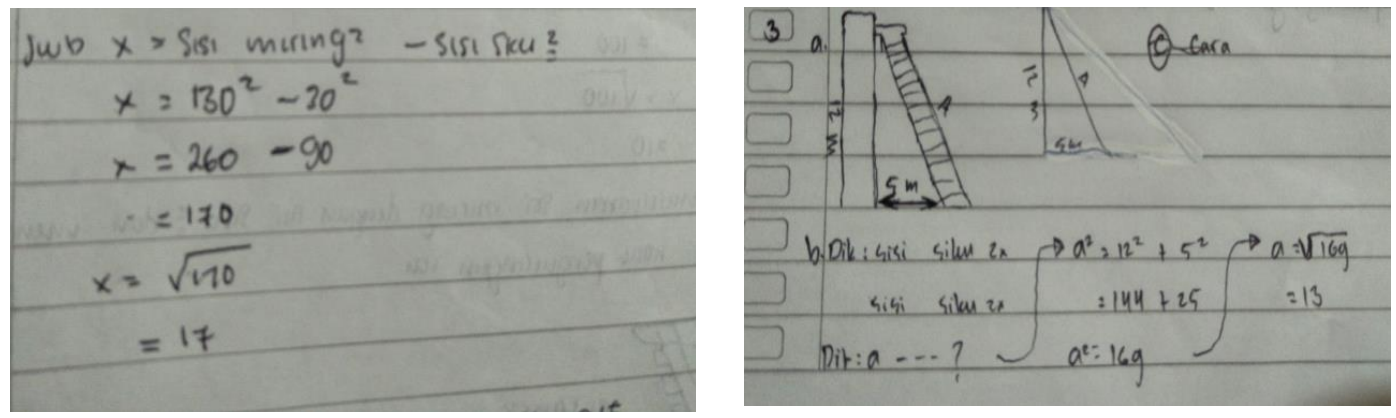

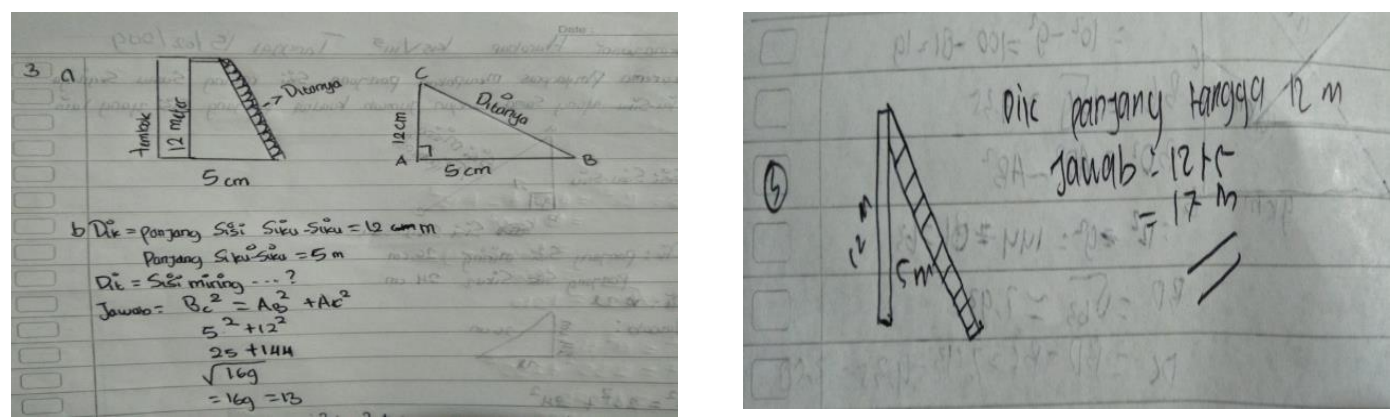

Gambar 3: Ragam Jawaban Siswa pada Soal Nomor 3

\section{Nomor 4}

Soal nomor 4 adalah soal yang bertujuan untuk mengetahui apakah peserta didik dapat menganalisis pengaplikasian konsep teorema pythagoras. Berdasarkan Tabel.1 ditemukan bahwa peserta didik yang memberikan jawaban dengan benar sebanyak 5 orang pada soal nomor 4 dengan persentase sebesar $23,80 \%$, yang menjawab salah sebanyak 16 orang siswa dengan persentase sebesar $76,19 \%$, dan tidak menjawab sebesar $0 \%$. Hasil tersebut dapat disimpulkan ternyata sebanyak 16 siswa melakukan 4 tipe kesalahan, yaitu: siswa dikategorikan mengerjakan kesalahan tipe-1 dimana siswa keliru dan bingung dalam pemahaman konsep dasar dari teorema pythagoras secara benar. Hal tersebut menandakan siswa tidak paham pada saat bagaimana suatu rumus tersebut digunakan karena ditemukan siswa salah mengaplikasikan rumus dengan soal sehingga siswa belum mengerti konsep dasarnya. Selanjutnya, siswa melakukan kesalahan pada tipe-2, yaitu perhitungan yang dilakukan siswa masih salah. Kemudian siswa masih mengerjakan kesalahan pada tipe-3 yaitu semua siswa tidak tepat mencantumkan satuan ukur yang benar. Kemudian, banyak ditemukan siswa tidak menuliskan rumus teorema pythagoras dengan benar dalam jawabannya sehingga diduga siswa saling mencontek satu sama lain. Selain itu, ada juga ditemukan bahwa siswa melakukan kesalahan pada tipe-4 yaitu, kesalahan prosedur dimana kurangnya kemampuan siswa dalam bidang aljabarnya. Siswa kurang mahir dalam memutar rumus dan siswa kurang memiliki kemampuan dan ketelitian dalam memahami soal cerita.

\section{Ragam Jawaban Siswa:}
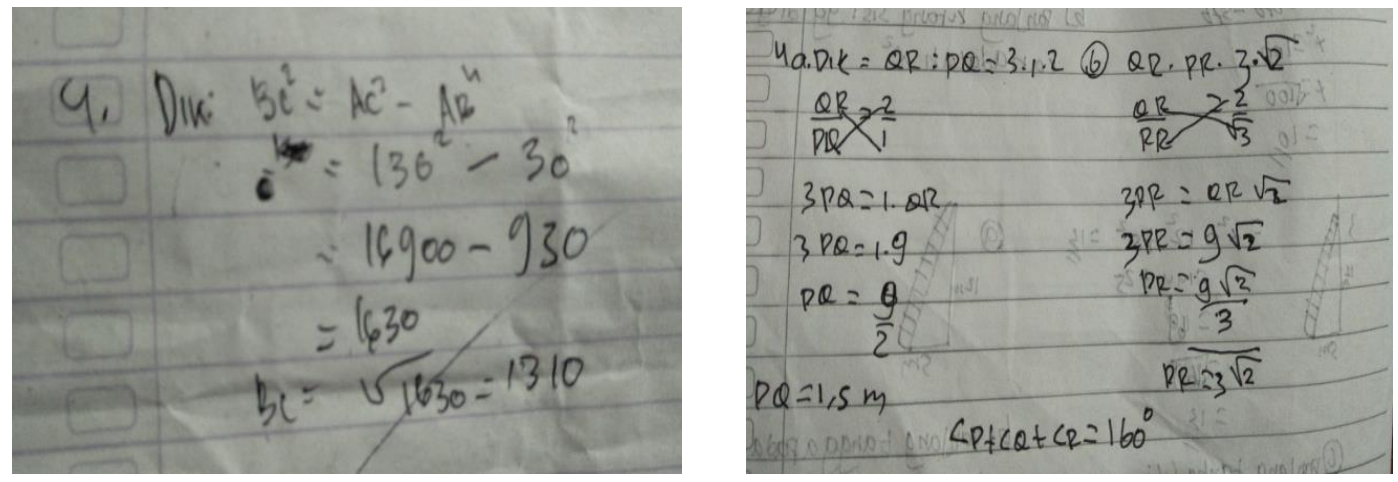

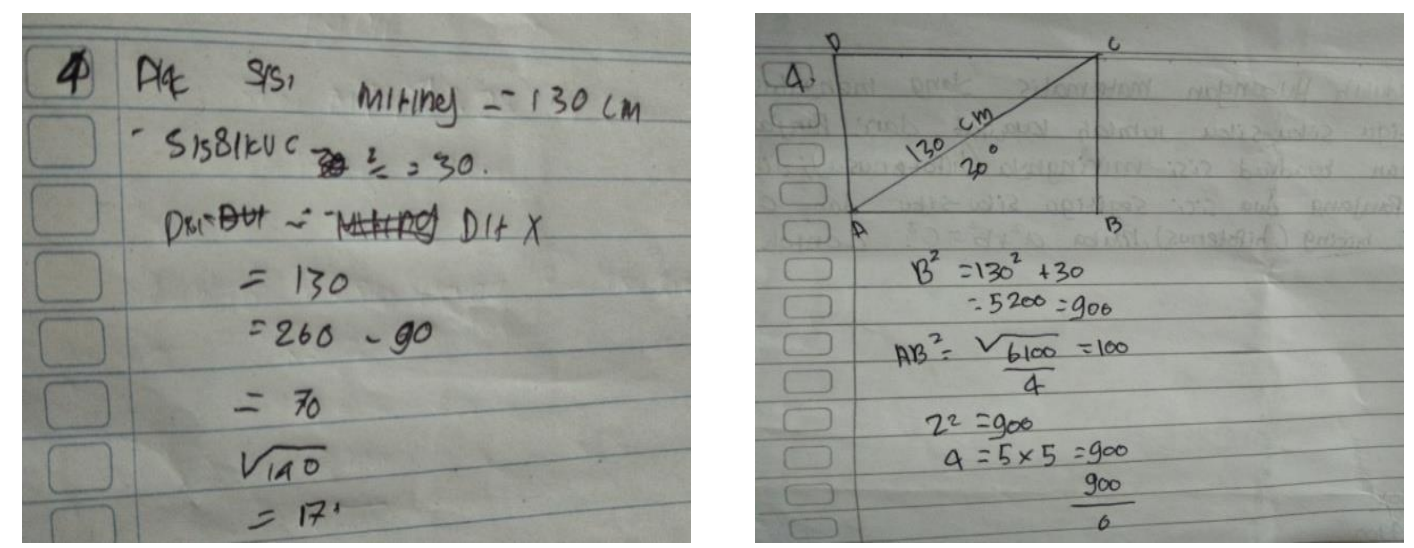

Gambar 4: Ragam Jawaban Siswa pada Soal Nomor Empat

\section{Nomor 5}

Soal nomor 5 adalah soal yang bertujuan untuk mengetahui apakah peserta didik dapat memahami penurunan rumus teorema pythagoras jika salah satu rusuknya tidak diketahui. Berdasarkan Tabel.1 ditemukan bahwa siswa yang menyelesaikan soal nomor 5 dengan benar sebanyak 0 siswa dengan persentase sebesar $0 \%$, menjawab salah sebanyak 21 siswa dengan persentase sebesar $100 \%$, dan tidak menjawab sebesar $0 \%$. Hasil tersebut dapat disimpulkan ternyata sebanyak 21 siswa melakukan 4 tipe kesalahan, yaitu: siswa melakukan kesalahan tipe-1 dimana siswa salah dalam memahami konsep dasar teorema pythagoras karena siswa masih bingung mengaplikasikan rumus ke dalam masalah yang ada pada soal. Selain itu, siswa tidak paham pada saat bagaimana suatu rumus tersebut digunakan, ditambah lagi siswa tidak mencantumkan rumus pythagoras dalam soal sehingga diasumsikan siswa saling mencontek dalam menjawab soal. Selanjutnya, siswa melakukan kesalahan pada tipe-2, yaitu perhitungan yang dilakukan siswa masih salah. Kemudian, siswa melakukan kekeliruan tipe-3 dimana siswa tidak menuliskan satuan ukur dengan benar $(\mathrm{cm})$. Selanjutnya, siswa melakukan kesalahan pada tipe-4 yaitu, kesalahan prosedur dimana kurangnya kemampuan siswa dalam bidang aljabarnya (menurunkan rumus/memutar rumus). Kurang memiliki kemampuan dan ketelitian dalam memahami soal cerita. Sebab pertanyaan berhubungan dengan penurunan rumus teorema pythagoras, namun masih ada siswa yang menjawabnya dengan mengalikan, menjumlahkan dan bahkan mengurangkan bilangan yang diketahui dalam soal. Selain itu, diasumsikan siswa tidak memahami soal dengan baik, sehingga informasi yang terkandung dalam soal tidak diketahui siswa. Berdasarkan hasil jawaban siswa pada soal nomor 5 walaupun tidak ada kalimat yang dianggap sulit namun dalam kenyataannya siswa tidak memaknai betul kalimat yang mereka baca. Hal ini terbukti bahwa siswa masih sulit meyelesaikan soal nomor 5 dengan mengaitkan teorema pythagoras pada soal cerita. 


\section{Ragam Jawaban Siswa:}
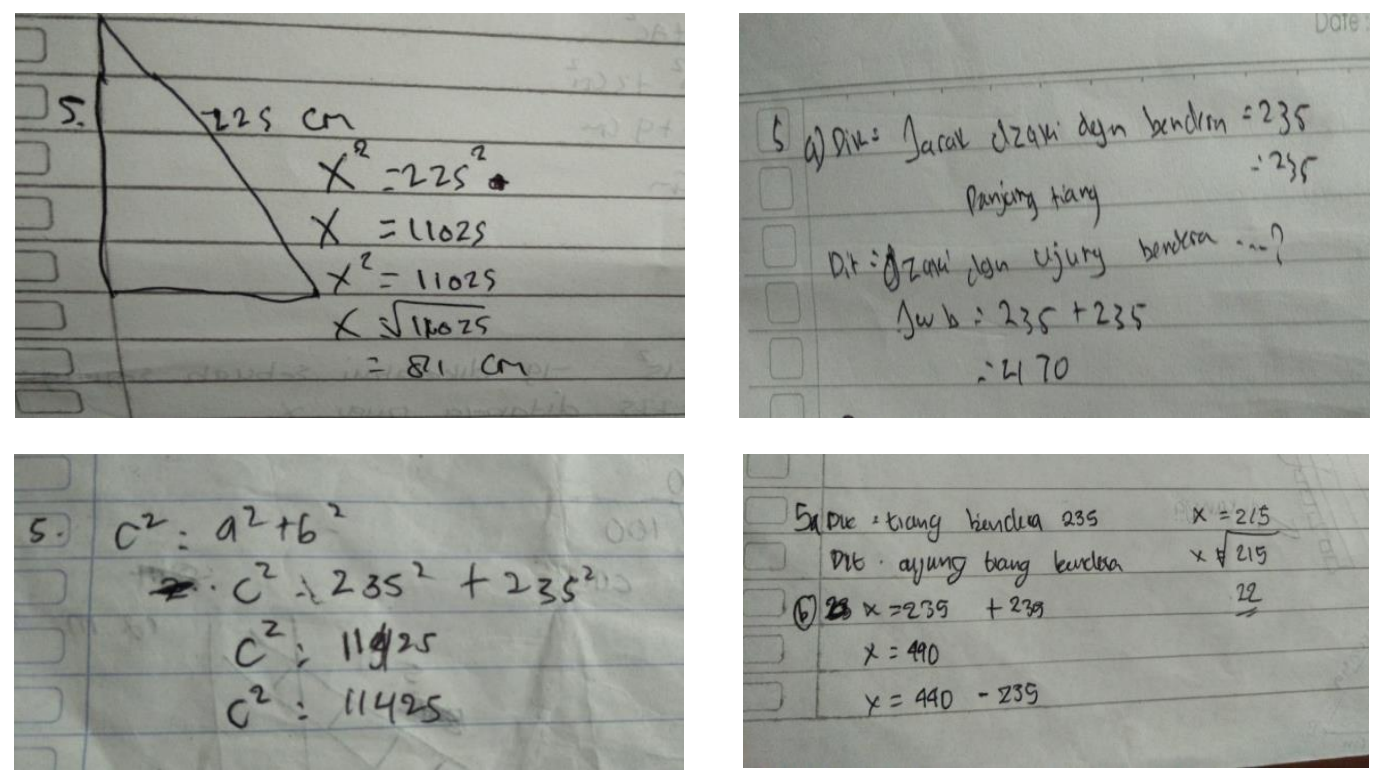

Gambar 5: Ragam Jawaban Siswa pada Soal Nomor Lima

Adapun setelah dianalisis hasil jawaban siswa dalam meyelesaikan soal cerita pada materi teorema pythagoras dapat dirangkum bentuk-bentuk kesalahan yang dilakukan siswa adalah sebagai berikut:

\section{Kesalahan Tipe-1}

Kesalahan tipe-1 ini merupakan kesalahan yang paling sering dilakukan oleh siswa karena pada dasarnya siswa masih lemah dalam memahami konsep teorema pythagoras, baik itu pengertian, sifat-sifat, rumus teorema pythagoras dan penurunannya. Selain itu, diasumsikan siswa tidak teliti dalam membaca soal atau mungkin kurang memahami soal dengan baik, sehingga informasi yang terdapat dalam soal tidak sampai pada siswa, serta siswa belum mengenal bentuk konsep pythagoras secara benar. Pada tahap membaca masih banyak ditemukan siswa tidak dapat melaluinya dengan baik, walaupun siswa dengan lancar bisa membaca soal dengan baik dan benar dikarenakan bentuk soal merupakan soal cerita yang menggunakan bahasa Indonesia yang mudah dicerna siswa. Namun siswa ternyata tidak dapat memaknai kalimat yang mereka baca secara tepat hal ini dapat dibuktikan bahwa pada memaknai perintah soal pada materi teorema pythagoras (soal nomor 1 sampai 5) banyak siswa keliru.

\section{Kesalahan Tipe-2}

Kesalahan tipe-2 ini merupakan kesalahan perhitungan yang dilakukan oleh siswa pada saat menyelesaikan soal. Pada dasarnya kesalahan perhitungan ini tidak begitu bermasalah pada siswa, namun jika siswa yang melakukan kesalahan dalam melakukan prosedur matematis, biasanya kesalahan itu terjadi sejak tahap pemahaman sehingga tahap ketrampilan proses ikut menghasilkan penyelesaian yang salah tetapi bukan kesalahan pada prosedur matematikanya. Pada tahap ini ditemukan siswa masih salah dalam menyelesaikan perhitungannya dan siswa 
tidak menuliskan rumus pada lembar jawabannya. Hal tersebut diasumsikan kurangnya latihan yang diberikan kepada siswa dalam melakukan operasi penjumlahan, pengurangan, perkalian, pembagian dan perpangkatan.

\section{Kesalahan Tipe-3}

Kesalahan tipe-3 ini merupakan kesalahan yang sering juga dilakukan oleh siswa karena diasumsikan kebanyakan siswa lupa menggunakan aturan satuan ukur dimana ditemukan banyak siswa tidak menuliskan satuan ukur dengan benar. Kalaupun ditemukan siswa menuliskan satuan ukur tetapi menggunakan satuan ukur yang salah. Selain itu, banyak ditemukan siswa belum mahir memberikan jawaban dengan menggunakan atau mengaplikasikan notasi matematika yang benar dan siswa tidak menuliskan rumus teorema pythagoras dan penurunannya dalam jawabannya. Sehingga diduga siswa saling mencontek.

\section{Kesalahan Tipe-4}

kesalahan pada tipe-4 yaitu, kesalahan prosedur dimana kurangnya kemampuan siswa dalam bidang aljabarnya (menurunkan rumus / memutar rumus). Kurang memiliki kemampuan dan ketelitian dalam memahami soal cerita. Sebab pertanyaan berhubungan dengan penurunan rumus teorema pythagoras, namun masih ada siswa yang menjawabnya dengan mengalikan, menjumlahkan dan bahkan mengurangkan bilangan yang diketahui dalam soal.

\section{Faktor-faktor Penyebab Kesalahan}

Pada analisis sebelumnya telah diuraikan beberapa faktor penyebab siswa mengalami kesalahan mulai dari kesalahan tipe-1 sampai kesalahan tipe-4 yaitu baik berupa kesalahan konsep, perhitungan, penulisan satuan ukur dan kesalahan prosedur dari setiap subyek pada setiap butir soal, meliputi: tidak bisa menyusun makna kata yang dipikirkan, kurang teliti, kurang memiliki kemampuan matematika, lupa, kurang latihan mengerjakan soal-soal bentuk cerita, serta kurang memahami soal.

Hasil dari penelitian yang telah dilakukan, kemampuan siswa dalam menerjemahkan soal cerita kedalam model matematika yang lemah akan mengakibatkan kesalahan pada langkah-langkah penyelesaian soal selanjutnya sehingga siswa tidak dapat menemukan jawaban yang tepat pada soal yang bersangkutan. Selain itu kemampuan siswa dalam menerjemahkan soal cerita ke dalam model matematika dan penyelesaiannya tidak lepas dengan adanya faktor kemampuan dari dalam diri siswa masing-masing, selain faktor-faktor tersebut kemampuan siswa dalam menyelesaikan soal dapat dilatih jika guru seing memberikan tugas latihan pada siswa. Jadi, semakin banyak diberikan latihan dalam menyelesaikan soal maka siswa akan semakin terampilan dalam penyelesaian soal.

\section{KESIMPULAN}

Salah satu kegiatan yang wajib dilakukan oleh guru setelah memberikan tes dan tugas kepada siswa adalah selain menilai hasil jawaban siswa, guru juga harus meerapkan analisis kekeliruan ataupun kesalahan-kesalahan yang sering dialami 
ataupun dikerjakan siswa dalam menjawab soal matematika. Berdasarkan hasil analisis pada pembahasan dapat disimpulkan bahwa rata-rata siswa yang mengerjakan soal dengan benar sebesar 49,518\%, dan rata-rata siswa yang mengerjakan soal dengan salah sebesar $50,47 \%$. Kesalahan paling banyak pada soal nomor 5, karena tidak ada siswa yang menjawab dengan benar. Kesalahan paling sedikit pada soal nomor 1, karena 19 orang siswa menjawab dengan benar. Kesalahan umum yang dilakukan siswa pada penelitian ini lebih banyak terjadi pada kesalahan tipe-1 yaitu pemahaman konsep, kemudian disusul oleh kesalahan tipe-3 yaitu kesalahan menuliskan satuan ukur, selanjutnya kesalahan atau kekeliruan tipe-2 yaitu kesalahan dalam proses menghitung serta kesalahan tipe-4 yaitu kesalahan tahapan ataupun prosedur matematisnya.

Kegiatan analisis kesalahan siswa ini pada dasarnya bertujuan agar guru dapat mengetahui kelemahan-kelemahan siswa dalam menyelesaikan soal matematika dengan demikian guru dapat melakukan bimbingan secara intensif maupun remedial teaching, selain itu guru juga bisa melakukan hal-hal yang harus diperbaiki dalam pembelajaran baik itu berupa pendekatan pembelajaran, media pembelajaran dan lain sebagainya yang mendukung kelancaran proses belajar mengajar dalam pelajaran matematika menjadi lebih baik lagi kedepan.

\section{DAFTAR PUSTAKA}

Agung, A. A. Gede, Metode Penelitian Pendidikan. Malang: Aditya Media Publishing, 2014.

Arti Sriati, Kesulitan Belajar Matematika pada Siswa SMA (Pengkajian Diagnosa), Jurnal Kependidikan, Yogyakarta, 1994.

Asih, I M, Peningkatan Kemampuan Siswa SMAN 8 Denpasar dalam Menyelesaikan Soal Cerita Pokok Bahsan Program Linear Mata Pelajaran Matematika, Denpasar: Universitas Udayana, 2011.

Md. Aditya Dharma, dkk, Analisis Kemampuan Menyelesaikan Soal Cerita Pada Siswa Kelas IV Tahun Pelajaran 2015/2016 di SD Negeri 1 Banjar Bali. Bali: Universitas Pendidikan Ganesha, 2016.

Mulyono Abdurrahman, Pendidikan Bagi Anak Berkesulitan Belajar, Jakarta: PT. Rineka Cipta, 1999.

Muncarno, Penerapan Model Penyelesaian Soal Cerita dengan Langkah-langkah Pemecahan Masalah untuk Meningkatkan Prestasi Belajar Matematika Siswa Kelas 1 SMP. Jurnal Nuansa Pendidikan Vol VI, No. 1, 2008.

Rahardjo, M. A, Pembelajaran Soal Cerita Operasi Hitung Campuran di Sekolah Dasar, (Modul Matematika SD dan SMP Program Bermutu). (Online) 
http://p4tkmatematika.org/file/bermutu.pdf, 2011. (diakses pada 25 Januari 2019).

Syamsuddin, H, Kesulitan Siswa Kelas V SD Menggunakan Langkah-langkah Pemecahan Masalah dalam Menyelesaikan Soal Cerita. Surabaya: UNESA, 2001.

Yunia Mulyani Azia, Upaya Mengatasi Kesulitan Siswa Belajar Geometri dengan Pengajaran Remidial Kelompok dan Remedial Bersama di Sekolah Lanjutan Tingkat Pertama. Diakses dari http://digilib.upi.edu/pasca/available/etd-1011106-131035/ 